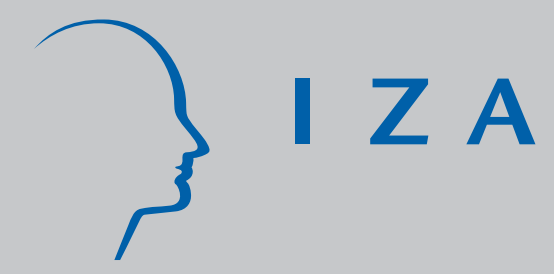

IZADP No. 2025

Beans for Breakfast?

How Exportable Is the British Workfare Model?

Olivier Bargain

Kristian Orsini

March 2006 


\title{
Beans for Breakfast? How Exportable Is the British Workfare Model?
}

\author{
Olivier Bargain \\ IZA Bonn
}

\section{Kristian Orsini}

K.U. Leuven

\section{Discussion Paper No. 2025 \\ March 2006}

\author{
IZA \\ P.O. Box 7240 \\ 53072 Bonn \\ Germany \\ Phone: +49-228-3894-0 \\ Fax: +49-228-3894-180 \\ Email: iza@iza.org
}

\begin{abstract}
Any opinions expressed here are those of the author(s) and not those of the institute. Research disseminated by IZA may include views on policy, but the institute itself takes no institutional policy positions.

The Institute for the Study of Labor (IZA) in Bonn is a local and virtual international research center and a place of communication between science, politics and business. IZA is an independent nonprofit company supported by Deutsche Post World Net. The center is associated with the University of Bonn and offers a stimulating research environment through its research networks, research support, and visitors and doctoral programs. IZA engages in (i) original and internationally competitive research in all fields of labor economics, (ii) development of policy concepts, and (iii) dissemination of research results and concepts to the interested public.
\end{abstract}

IZA Discussion Papers often represent preliminary work and are circulated to encourage discussion. Citation of such a paper should account for its provisional character. A revised version may be available directly from the author. 


\section{ABSTRACT \\ Beans for Breakfast? How Exportable Is the British Workfare Model?*}

Social assistance and inactivity traps have long been considered amongst the main causes of the poor employment performance of EU countries. The success of New Labour has triggered a growing interest in instruments capable of combining the promotion of responsibility and self-sufficiency with solidarity with less skilled workers. Making-work-pay (MWP) policies, consisting of transfers to households with low earning capacity, have quickly emerged as the most politically acceptable instruments in tax-benefit reforms of many Anglo Saxon countries. This chapter explores the impact of introducing the British Working Families' Tax Credit in three EU countries with rather different labor market and welfare institutions: Finland, France and Germany. Simulating the reform reveals that, while first round effects on income distribution is considerable, the interaction of the new instrument with the structural characteristics of the economy and the population may lead to counterproductive second round effects (i.e. changes in economic behavior). The implementation of the reform, in this case, could only be justified if the social inclusion (i.e. transition into activity) of some specific household types (singles and single mothers) is valued more than a rise in the employment per se.

JEL Classification: $\quad$ C25, C52, H31, J22

Keywords: tax-benefit systems, in-work benefits, microsimulation, household labor supply

Corresponding author:

Kristian Orsini,

CES - KU Leuven

Naamsestraat 69

Leuven

Belgium

Email: kristian.orsini@econ.kuleuven.be

\footnotetext{
*We are grateful to Tony Atkinson, Denis Beninger, François Bourguignon, Tim Callan, André Decoster, Marc Gurgand, Seija and Pekka Ilmakunnas, Herwig Immervoll, Thomas Picketty, Cathal O'Donoghues, Holly Sutherland, Heikki VittamÄaki and Sile O'Dorchai for useful comments and advices. All errors or omissions remain ours. This chapter was written as part of the MICRESA (Micro Analysis of the European Social Agenda) project, financed by the Improving Human Potential programme of the European Commission (SERD-2001-00099). For the countries considered in this paper, EUROMOD relies on the following micro-data: the Income Distribution Survey made available by Statistics Finland; the Household Budget Survey made available by INSEE, the German SocioEconomic Panel Study made available by DIW.
} 


\section{Introduction}

From a labour supply perspective, high tax wedges coupled with generous minimum income and unemployment benefits are perceived as one of the main causes of persistently lower employment rates of less skilled workers, since they make work financially unattractive. The picture is particularly dramatic when employment rates are broken down by gender. According to recent Labor Force Survey statistics, female employment rate in EU15 is just above $65 \%$ in 2004 (i.e. 20 percentage points lower than the male employment rate), while the employment rate for low skilled women is as low as $46 \%$, with almost half of active women being marginally or part-time employed. Any attempt to increase employment rates in Europe should therefore primarily target this group.

Employment policies in Europe have traditionally relied on labor demand levies, such as subsidies and targeted social security contribution (SSC) reductions (Martin and D.Grubb, 2001). Recently, however, the unquestionable success of New Labor in the UK has triggered an increased interest in supply side measures. In recent years, while unemployment rates have increased in many EU countries and employment rates have been stagnant, the UK has seen its unemployment rate falling to just under $5 \%$. Even more remarkably the employment rate of females has increased by almost 3 percentage points.

Making Work Pay (MWP) policies - i.e. policies that tackle low employment from a labor supply perspective through employment conditional transfers - have been held responsible for the successful labor market dynamics in the UK.

Following the pioneering measures in the US and the UK - the Earned Income Tax Credit (EITC) and the Working Families' Tax Credit (WFTC) respectively -, several European countries are now looking with renewed interest at such policy instruments.

Indeed as argued by Banks, Disney, Duncan, and van Reenen (2003), the globalization of knowledge has lead to increased opportunities to learn from the experiences of other countries. According to the authors, this has been particularly evident in the case of labor market policies, retirement and saving policies and indeed in 'making work pay policies'.

That the analysis of successful experiences in other countries have recently gained the interest of policy makers is witnessed by several studies carried out by their advisors. For example, in a government report on employment and economy perspectives for the next decades, Ilmakunnas, Kiander, Parkkinen, and Romppanen (2000) do no exclude that Finland may recur to earned income tax credits similar to those employed in other countries. While underlining the success of such policies the board of advisors are cautious about the effects in a different economic and institutional settings. In the report of the advisory board of the German Ministry of Economics and Technology on employment of the low skilled (Bundesministerium für Wirtschafts und Technologie, 2002), the authors analyze in detail the British WFTC and the American EITC. They even simulate the introduction of the EITC in the German context, but only on some typical households. Finally they argue that the extent to which a German reform of low skilled employment should resemble other international experiences is mainly a political issue. In the French context, the British WFTC experience has been cited twice in the reports of the economic advisory board of the prime 
minister. ${ }^{1}$ Most striking are perhaps the words of Maarek in commenting the advisory report of Bourguignon and Bureau (1999):

"It is now time to seriously look at some form of negative income tax. This is no longer a simple intellectual speculation. The reforms could be inspired by the American EITC, or the British WFTC [translated from French]"

Indeed, policymakers are mostly attracted by the capacity of MWP to combine solidarity and the promotion of self-sufficiency. However, the extent to which these instruments may be successfully implemented in the context of central European countries and Scandinavia, has not yet been thoroughly analyzed. This chapter aims at assessing the validity and applicability of MWP policies to the European context, by looking at three EU countries - France, Germany and Finland - that despite being characterized by different institutions and so called 'framework conditions', all characterized by inactivity traps. France and Germany have indeed struggled to increase employment rates in the past years, while unemployment rates have kept increasing. Germany, moreover, continues to show lower employment rates for mothers, and a higher share of part-time work. On the other hand, in the years following the early 90s' recession, Finland has been characterized by declining unemployment rates and increasing employment rates. Yet unemployment amongst the low skilled population remains extremely high, as compared to other Scandinavian countries.

It is not surprising that these countries, as well as several other EU countries have looked with interest at the British policies. The relative consensus on the need for implementing MWP policies is however muddied by concerns about efficient policy design, with respect to the structural characteristics of the population and of the economy and the general objectives pursued.

The institutional context in which the policy implementation takes place (i.e. existing taxbenefit system, presence of a minimum wage, etc.) as well as the shape of wage and income distributions and the size of labor supply sensitivities are known to have a deep impact on the effectiveness of such instruments. Moreover it is dubious that redistributive and efficiency objectives may be pursued with equal intensity by a single policy measure. ${ }^{2}$ Being means-tested on household income, policies in the fashion of the WFTC and the EITC are known to be well targeted at households in need but may indeed discourage the work of women in two-earner couples.

All these aspects will be analyzed in a comprehensive way by simulating the implementation of a pseudo-WFTC in the tax and benefit legislation of the three aforementioned countries.

The structure of the chapter is as follows: section 2 describes the British experience and explain how the WFTC was modified to be adapted to the countries at stake. Section 3 describes the pre reform tax benefit systems and analyzes how the budget constraints were modified. Section 4 provides a static analysis of the reform in terms of budgetary costs and effects on poverty, while section 5 analyzes different indicators to derive plausible expectations of labor supply effects.

\footnotetext{
${ }^{1}$ See Bourguignon and Bureau (1999) and Ferry (2000)

2 This difficulty is illustrated by the recent changes in the UK tax system where the WFTC has indeed been split into two distinct policies serving different objectives: a working tax credit to create incentives to work and subsidize working poor and a child tax credit to redistribute toward families and children (Brewer, 2003).
} 
Section 6 concludes.

\section{Simulating the British Experience}

In-work benefits such as the EITC and the Family Credit and it successor - the Working Families' Tax Credit - have been in place for over twenty years in the US and in the UK respectively. Canada, Ireland and New Zealand have also had a relatively long experience with such schemes. In recent years MWP are rapidly gaining policy makers' interest in continental Europe as well where there is a widespread consensus on the need for such policies (Banks, Disney, Duncan, and van Reenen, 2003).

The official objective set forth by policy makers is double: (i) to expand employment by increasing work incentives, (ii) to increase income of disadvantaged groups (Pearson, 2002). The second objective is clearly redistributive and in-work benefits seem an interesting way to redistribute to a subset of the poor population known as the 'working poor'. Such instruments can be seen as more politically acceptable than a rise in social assistance - given the feared increase in work disincentives - and more efficient than an increase in the minimum wage, which might push up wage rates above the market equilibrium and hence lower the employment rate.

The British Working Families' Tax Credit has attracted considerable attention from researchers and policymakers. From a political point of view, the tax credit represents one of the most celebrated achievements of the Blair administration in the current and passed legislation, and a concrete application of the New Labour ideology. Its (potential) effects have been evaluated in several studies from a variety of perspectives and using different methodologies (see Brewer and Shephard (2004) for a review). The WFTC represents therefore a 'natural candidate' for transposing in-work benefits in Continental and Scandinavian welfare systems. At the same time, as it will become clearer in the discussion, some minor adaptations will be needed in order to ensure coherence between the simulated benefit and the tax benefit system in each country.

\subsection{The Working Families' Tax Credit in the UK}

In October 1999, the WFTC replaced the Family Credit (FC), by maintaining the main framework of the older benefit and substantially increasing the income range of eligibility. The basic WFTC transfer is conditioned on at least one of the adults in the household being in paid work (employment or self-employment) for at least 16 hours per week. Once household income reaches the threshold level, the maximum amount is tapered away, at a rate of $55 \%$ as household's income increases. Income, however, is assessed after income tax and contributions have been paid, so that, in the phase out range, the withdrawal rate with respect to gross income is $37 \%$. The maximum amount of benefit increases with the number of children (the basic transfer increases by $49 \%$ for every child). Moreover a premium corresponding to $20 \%$ of the basic transfer is awarded if one household member works at least 30 weekly hours. The new WFTC also introduced a deductability of $70 \%$ of approved child care, up to a maximum of 150 pounds/week. 
While MWP policies in the fashion of the WFTC unequivocally encourage the participation of singles, it is often the case that they discourage second-earners in couples, bringing about a gender bias against the participation of women. Moreover, the generosity of the reform implies a sharp taper rate in the phase-out range of the measure. Average tax rates are hence lowered at the cost of an increase in effective marginal tax rates (EMTRs hereafter) generating disincentives at the intensive margin (see Eissa and Hoynes (2004) and Blundell, Duncan, McCrae, and Meghir (2000)).

Ex-ante predictions based on microsimulation software and structural models of labor supply were partially confirmed by ex post analysis using the 'difference in differences' methodology (Brewer and Shephard, 2004) as well as by official statistics. Using the Family Resource Survey and the tax-benefit model TAXBEN3, Blundell, Duncan, McCrae, and Meghir (2000) have evaluated ex-ante the labor supply responses to the WFTC. It is found that nearly $80 \%$ of lone parents in part-time employment (between 16 and 30 hours per week) benefit from the reform. As for couples, the credit is more generous for one-earner households, a third of which would be entitled to the tax credit. The impact on hours is ambiguous as the number of households with an EMTR above $70 \%$ decrease by around 450,000 while households with an EMTR above $50 \%$ increase by about the same amount. This is due to a lower taper rate ( $55 \%$ instead of $70 \%$ with the FC) entailing a smaller positive impact on EMTRs but for a larger number of people. The net change in participation rate would consist of an increase by 2.2 percentage points for single mothers (34,000 individuals) and a decrease by 0.57 percentage points (20,000 individuals) for married women with employed partners. Combining all the behavioral effects, the WFTC leads to a small increase in overall participation, by just above 27,000 individuals. Labor supply responses to the WFTC should act to reduce the cost of the program by around 14\%. Brewer, Duncan, Shephard, and Suárez (2003) used a more general model (with selective programme participation) and find similar results. However, comparing the results with ex-post data, the authors find that the overall participation rates of both females and males in couples decreased. Indeed, the policy mix between April 1999 and April 2000 also increased social aid for households with children under the age of 11. The generous policies aiming at a drastic decrease of child poverty have therefore partially reduced the positive effect of the WFTC. Yet the employment rates of lone mothers increased by almost 3.4 percentage points.

Few works assess the impact of the measure from a distributional perspective. Pichaud and Sutherland (2002) decompose the effect of different policy measures in a static framework and conclude that while Labour policies have been rather effective in reducing poverty risk amongst children (with almost one million children being lifted out poverty from tax benefit reform), other groups have been significantly neglected, so that overall poverty rates were not characterized by a significant reduction. 


\subsection{Simulating a Working Tax Credit in France, Germany and Finland}

Policies aiming at increasing the financial incentives of employment have been implemented in most EU countries in the previous decade. Germany and Finland have aimed at reducing the tax burden on labor income through allowances and tax rebates, whereas France has gone one step further, by introducing a refundable tax credit (see Laine (2002), Haan and Steiner (2005) and Bargain (2004) for details on Finnish, German and French reform respectively).

The budget allocated to these recent reforms, however, is well below the level of transfers implied by the British schemes. Even the most generous reform, i.e. the German tax reform, will imply a maximum net gain of slightly over 1000 EUR, well beneath the British WFTC.

An additional motivation for the present study is to question what could have happened, had these countries dedicated the same budgetary expenses as the UK to MWP transfers.

The rules and the amounts of the new tax credit to be simulated in France, Germany and Finland match closely those of the British 2001 WFTC. However we apply the tax credit to the tax and banefit system of $1998 .{ }^{3}$ Eligibility requires that at least one of the adults is in paid work for at least 16 hours per week. The formula to compute total household entitlement to the tax credit is as follows:

$$
T C=B-\max (0 ;(z-\theta) t)
$$

The maximum theoretical amount of the benefit $B$ is composed of a basic transfer of EUR 3880 plus the additional $49 \%$ of the basic transfer per dependent child and the $20 \%$ premium for working more than 30 hours. The threshold or disregard, $\theta$, amounts to EUR 6671 while the the taper rate $t$ equals $55 \%$. Note that while this corresponded roughly to $37 \%$ on gross income in the UK, the corresponding percentage will vary across the countries we examine, due to differences in the level of social security contributions and income tax.

Fig. 1 shows the amount of the credit in EUR/year when total weekly working hours increase from 0 to 80 (at a net hourly wage rate of 6 EUR/hour). The 16 hour and 30 hours thresholds are particularly evident, as they mark the eligibility and premium conditions respectively.

The basic idea behind the British WFTC is to design a benefit that increases the financial incentives for poor households of being in paid work. The transfer, which is conditioned on at least one adult being in paid work, is substantially higher than the minimum income. The structure

\footnotetext{
${ }^{3}$ To this extent British amounts have just been deflated to 1998 and multiplied by the exchange rate (0.679 $£$ /euro). Since the construction of an integrated microsimulation model such as EUROMOD is extremely labor intensive, policy rules are not immediately updated for all countries and are hence available only for some reference year (e.g. 1998, 2001 and in the near future 2003). Moreover even if more updated policy rules were available, in order not to draw biased conclusions, one should use tax and benefit rules that are not to distant in time from the year in which the microdata was collected. Indeed some important reforms were introduced in France between 1998 and 2001, and Germany too has implemented a significant tax reform and a change in the unemployment insurance, that are likely to modify the labor supply of households. The use of an older system implies a more consistent estimation of the effects of the reform. The main drawback is of course that the analysis is not fully up to date with respect to changes in the tax and benefit system and the current economic situation.
} 
of the benefit, including unit of assessment, definition of qualifying child and income concept, is the same as for the minimum income scheme. The potential gains of WFTC eligibility are hence homogeneously extended to all households (with adults in working age) in social assistance.

In assessing income all main sources of income are included net of tax and social security contributions. These include earnings, self-employment income, unemployment benefits, pensions, irregular incomes, capital income and maintenance income. The main excluded incomes are the Child Benefit, the Maternity Benefit, the Statutory Maternity Pay, and some minor UK specific disregards on maintenance payments and war pensions. At the same time, the amount of the WFTC enters the assessment of the Income Support so that when receiving the WFTC, a households looses eligibility to the Income Support. Moreover, households eligible to income assistance are automatically eligible for the full housing benefit, whereas the latter is tapered away for higher levels of household income (including the WFTC transfer). The net effect of the WFTC tends therefore to be much smaller, as eligibility to the in work benefit reduces the transfers from other schemes.

In implementing the reforms in the countries we consider, we have tried to preserve the same logical structure, while keeping the tax credit as close as possible to the WFTC. Eligibility conditions and income assessment rules were therefore adapted in an effort to balance cross country comparability and coherence with each country's social assistance legislation.

In France, the assessment is the same as for the social assistance schemes (Revenu Minimum d'Insertion and Allocation pour Parents Isolés), but similar to the WFTC the generous child benefit (Allocation Familiale) where excluded from the income assessment. In Finland and Germany, on the other hand, income assessment for existing social assistance benefits (Toimeentulotuki in Finland, Sozialhilfe in Germany) are already net of the universal child benefit. Other minor income disregards existing in each country's social assistance legislation were not modeled.

Similarly to the UK, we retain the definition of a qualifying child used for social assistance in each country. While this choice might in theory generate slightly more advantageous schemes in some countries (e.g. in Germany, where there is no age limit for qualifying child), it is unlikely that the latter will play a major role, given that there are very few households with grown up children.

A third issue concerns the interaction of the credit with other means tested instruments. As in the UK, the WFTC enters the assessment of the national social assistance schemes. ${ }^{4}$

Differently from the UK, however, we decided not to model any "direct" interaction with the housing benefit, in order to avoid multiple interferences. ${ }^{5}$ Due to the latter, the net transfer will

\footnotetext{
${ }^{4}$ Like in the UK, the credit does not enter the means test for child benefits in France, while no such means tested child allowance exist in the other countries.

${ }^{5}$ In Finland the amount of housing benefit enters the assessment of social assistance eligibility (and hence of the tax credit), while in Germany the interaction is reversed since social assistance determines the type and level of housing benefits. In France the interaction between social assistance and housing benefit is even more complex: if a household is theoretically eligible to a positive level of social assistance, labor income or replacement incomes (unemployment benefits) are not accounted for in the income assessment for the computation of housing benefits, but the level of the housing benefit then determines the actual amount of the social assistance.
} 
be comparatively higher than in the UK, since eligibility to the WFTC does not cause the housing benefit to be withdrawn. This choice partially reflects the different role of the housing allowances in continental Europe and in Scandinavia. Although means tested, these benefits are designed to enhance affordability of housing costs. In the UK, housing benefits mainly function as an additional safety net, which explains why they are withdrawn as households become eligible for WFTC. ${ }^{6}$

Other than the aforementioned country specific adaptations, the main difference with the WFTC is that childless households are also eligible to the credit. The credit thus anticipates some of the features of the 2003 reform of the British system. The new structure involves two separate credits: a refundable Child Tax Credit (CTC) to support children in low-income families, regardless of the work status of the parents, and a Working Tax Credit (WTC) now extended to childless singles and couples. ${ }^{7}$

\section{Interaction with the Tax and Benefit System}

When comparing the effects of a reform on several countries, it is important to review the initial conditions that affect the policy's effectiveness. The final effect of a reform, and its budgetary cost, may differ substantially across countries due to differences in the structural characteristics of the economy and of the population. It is indeed the consideration of such structural characteristics that may help policymakers evaluate how appropriate an instrument may be for pursuing a defined objective.

In particular, some framework conditions affect directly the reshaping of financial incentives to work. The interaction of the new tax credit with the tax-benefit system determines the distribution of Effective Marginal Tax Rates (EMTR) faced by households, as well as the financial gains when switching from inactivity to employment. Even though the importance of these initial conditions has been stressed in previous studies, they have not been sufficiently exploited in large-scale analysis using microsimulation models and even less so within multi-country comparative framework. ${ }^{8}$

Other important framework conditions that affect the extent of the eligible population and the

\footnotetext{
${ }^{6}$ Stephens, Burns, and MacKay (2002) critically assess the different instruments of the British housing policy with respect to the experience of other EU countries, including Germany, France and Finland. The authors stress the different ideology underlying housing subsidy in the UK with respect to most other countries.

${ }^{7}$ It should be noted that our reform does not correspond to the reform implemented in the UK in 2003. In the new British system, the child premia for couples is universalized in a new instrument (the Child Tax Credit) available to both active and inactive households. Simulating the new system would have implied designing an additional harmonization of family benefits and social assistance scheme in all three countries. Indeed, the basic idea of the WFTC is to recreate significant financial difference between social assistance and paid work. Since the former is scaled on family size in France, Germany and Finland, the tax credit must also include a child dimension in order to tailor the financial gains from taking up work to the income level guaranteed by minimum schemes. Moreover the new British system simultaneously increase income out of work (through the refundable child tax credit) and in employment (through increased working tax credit). In this sense, distributional (towards households with children) and efficiency concerns are clearly addressed by two separate instruments, whereas it is the scope of this paper to assess weather a single measure may attain both objectives simultaneously.

${ }^{8}$ See Pearson and Scarpetta (2000) and Bertola (2000).
} 
average amount of the transfer are known ex ante and do not require a microsimulation software to be analyzed. These include the distribution of households according to their composition, as well as the distribution of activity rates and household income. The latter set of framework conditions will be analyzed in conjunction with the distributional impact of the reform in the following section. The former set of framework conditions will be analyzed in section 5 and will be used to cast some light on potential behavioral adjustments. In the current section we will instead concentrate on each's country tax and benefit system and analyze how the budget constraint is modified when introducing the tax credit. This analysis, although based on hypothetical households, allows for a first intuition of the effects of the interaction of the different instruments and its potential impact on income distribution and work incentives.

\subsection{Pre and Post-Reform Budget Constraints}

The budget curves in fig. 2 shows pre and post reform budget constraints for a single earner and for a secondary earner in a couple with two children. Gross earnings are on the horizontal axis and disposable income on the vertical axis. Each unit on the $\mathrm{X}$ axis represents an increase in gross income corresponding to a unitary increase in weekly working hours, times a fixed gross hourly wage (in this case 6 EUR). ${ }^{9}$ In the case of couples, the increase in earnings of the secondary earner adds up to the earning of the other spouse, whose earnings correspond to working full time at the same wage rate.

The analyzed countries differ profoundly with respect to shape of personal income tax, weight of social security contributions and relative importance of family related and other benefits. ${ }^{10}$ However, the crucial aspect here is the relatively flat region which characterizes single earners in all three countries and clearly illustrates the inactivity trap. Despite some differences in eligibility rules, disregarded incomes and benefit level, minimum income schemes usually share a common structure: they are means tested on net income. This implies that every additional euro of net income is automatically offset by the loss of a euro of social assistance. In term of effective marginal tax rates, households on welfare are then characterized by an implicit $100 \%$ taxation of their earnings.

In year 1998, German minimum income was more generous than in Finland and in France. The minimum income for a single was 4650 EUR per year in Germany, and about 4000 in Finland and France, whereas the amounts for a lone parent with two children corresponded respectively to 9627,6283 and 5432 EUR. ${ }^{11}$ France, however, relies on a combination of minimum income and generous housing benefits. The latter is phased out at a very slow rate but does not enter the

\footnotetext{
${ }^{9}$ An additional assumption was made concerning the cost of housing. While this information is reported in the survey data, in draw the budget set of typical households, we assumed housing cost in the order of 500 EUR/month.

${ }^{10}$ See in-depth descriptions of the tax-benefit systems in Bargain and Terraz (2001) for France, Grabka (2001) for Germany and Vittamäki (2001) for Finland.

11 The level of 'safety net' is very similar in all three countries, due to the fact that housing benefits play a larger role in France (3,000 euros for an inactive person, i.e. 44\% of her disposable income) and Finland (2, 000 euros, i.e. a third of her disposable income) than in Germany (1, 200 euros, $20 \%$ of her disposable income).
} 
income assessment of social assistance, which explains why the first segment is slightly negatively sloped.

More generous minimum income in Germany makes the flat segment longer than in France and Finland. However, small amounts of labor income (70 EUR per month) are entirely disregarded, which explains the small portion of the curve displaying a 45 degree slope; additional earnings are partially disregarded (30\%) up to a maximum of 140 EUR of disregard, which corresponds to the second positively slopped portion of the curve. Beyond such threshold, however, the withdrawal rate is of $100 \%$.

Working full time at an hourly wage rate of 6 EUR is enough to earn an income above the social assistance threshold (for a couple with two children) in France and in Finland, but not in Germany. This explains the small flat segment even in the graph on the right hand side. As the secondary earner increases the labor supply, household disposable income increases in all countries, but the rate of the increase is different due to differences in social security contribution (SSC) and personal income tax (PIT). In the case of Finland, taxation of low incomes is quite low, which explains a steeper budget curve (i.e. closer to the $45 \%$ line). In France, PIT is typically low, but SSC are high (and contrary to income tax, not progressive). Moreover, the aforementioned phasing out of the housing benefit accounts for the somewhat flatter profile of the budget constraint. In Germany, on the other hand, both SSC and PIT tend to be high even at low incomes.

In the case of singles, the aforementioned 16 and 30 hours thresholds are particularly evident in the shape of the budget constraint. The difference between pre and post reform disposable income appears to be much smaller than the amount of the tax credit, which is due to the fact that the tax credit enters income assessment for social assistance, and thus crowds out such benefit. This effect occurs in all countries and is maximum in the case of Germany, due to a more generous safety net. The maximum net gains are therefore in a range between 10,000 and 15,000 EUR. It appears, however, that in all countries, the reform creates a significant financial difference between non-participation and full-time activity, unambiguously enhancing the probability of participation for single individuals or lone parents. Also the phasing out of the benefit is much slower in the case of Germany: this is due to the fact that heavy social security contribution reduce the net income.

When looking at the secondary earner case, the kinks in the budget curve are no longer visible: indeed it is the first earner that opens up eligibility to the tax credit. This implies that when the secondary earner starts working, he or she are already in the phase out range of the benefit, which implies that increased working effort and higher gross earnings are transformed into negligible increases in household disposable income. The relative sharpness of the phase out is moreover affected by the slope of the pre reform budget constraint.

\section{Budgetary Cost and Effects on Poverty}

In this section we will concentrate on the analysis of the first round effects of the reform. In other words, we will look at the distributive effect of the change in the budget constraint, without taking into consideration possible behavioral reactions. The analysis will also review the budgetary cost of 
the reforms and compare them across countries. In order to explain the differences, we will review the different initial or framework conditions which affect eligibility conditions and the amount of the entitlement. To this extent we will first consider the distribution of employment rates and household income, as well as the structure of household composition.

\subsection{Household Structure and Employment}

Participation rates give a first indication on the proportion of households potentially eligible to the in-work benefit. More precisely we may look at the proportion of households with at least one member working a minimum of 16 hours per week. Table 1 shows the proportion of these 'potentially eligible' households, in percentage of the total number of households with head or spouse in working age. Other than the employment rate, also the distribution of the potentially eligible households in the benefit range is a matter of primary concern. The number of eligible units, and their distribution in the benefit range determines not only the cost of the measure, but also the size of potential behavioral responses. The share of non eligible units is highest in Germany, whereas in France and in Finland only one household out of three is not eligible The distribution of eligible households in the benefit range, on the other hand, appears to be very similar across the three countries, given that the share of households out of the benefit range is substantially higher in France and in Finland (56.8\% and $44.8 \%$ respectively), than in Germany $(44.8 \%) \cdot{ }^{12}$

With respect to the population in the benefit range, Finland shows a slightly higher concentration of households in the phase out range (14.3\% as compared to $13.1 \%$ and $13.7 \%$ of France and Germany respectively), whereas France has the highest share of households in the maximum benefit range (1.1\%, i.e. from 4 to 3 times higher than Germany and Finland).

The previous picture, nevertheless, hides substantial differences in the structure of the eligible population. The latter not only will affect the redistributive power of the reform, but will also have a substantial impact on the size and direction of the potential behavioral adjustment. Crucial elements of the analysis are (i) the share of singles and couples, (ii) the relative share of single (male) breadwinner and double earner households and (iii) the share of households with and without children. This information is summarized in table 2 ; household types are classified in accordance to the structure of the household and female employment status (since there is very limited variation in the employment status of males) The households considered are headed by potentially active singles or couples, only. Elderly households as well as more complex household structures are not included in the sample as this is a rather heterogeneous group, characterized by

\footnotetext{
12 The distribution of the population in the benefit range determines the first round distributional impact of the reform. The fact that the share of the population in the benefit range is of comparable size and distribution implies comparable aggregate costs. However, the share of non eligible units and the share of units in the phase-out range or out of the benefit range provide intuitions on the size of potential behavioral responses. Households in the phase out range and to a lesser extent households whose income is higher than the benefit range may in fact reduce their labor supply, whereas non eligible households might increase it to enter the benefit range. The scope for positive reactions is clearly smallest in France and in Finland, and largest in Germany.
} 
law eligibility rates.

A first striking aspect is the difference in the share of singles: Finland has almost twice the share of single adult household than France (24.7\% and $16.6 \%$ respectively), whereas Germany is closer to Finland. Between half and one third of single female households are inactive, but the share of inactive single mothers is extremely low in France and in Finland, but substantially higher in Germany. France has therefore the lowest share of singles, but shows also the highest activity rate amongst this group. For sake of comparison, in year 1998, the share of single mother households was slightly under $5 \%$ in the UK, with almost half of the single mothers being inactive.

Potentially eligible households are also encountered amongst couples and especially couples with children, where the benefit range is widest. France has the highest share of couples with children, but again the employment rate of secondary earners (i.e. mostly females) is rather high, which implies that a higher shares of households might be pulled out of the benefit range.

The share of active women in couples with and without children is highest in Finland $(15.0 \%$ and $11.9 \%$, respectively), and lowest in Germany (7.9\% and 9.1\%, respectively). France has slightly lower employment rates than Finland, but the share of working mothers is as high as $17.7 \%$.

\subsection{Aggregate Statistics}

The aggregate impact of the reform is summarized in table 3. The apparent cost is aggregated expenditure on the instrument, whereas the net cost is the net increase in public expenditure. The latter is indeed smaller than the former, due to the fact that spending on the tax credit crowds out spending on other transfers, mainly social assistance transfers, but also (in the case of Germany) housing benefits.

Apparent cost is slightly smaller in Germany (0.36\% of GDP) than in France or Finland (around $0.40 \%$ of GDP). In absolute terms, the cost of 5.8 billion EUR in France and 7.6 billion in Germany can be compared to the $£ 5$ billion spent in 2001 in the UK on the WFTC (7.3 billion EUR).

However, net costs are much smaller in the case of Germany (0.29\% of GDP). The reason for this, is the high generosity of social assistance. Indeed, as shown in fig. 2, a single breadwinner household with two dependent children (with the breadwinner working full time at a low wage rate), and a single adult with two dependent children working more than 16 hours per week are still entitled to social assistance benefits. The introduction of the tax credit, then simply shifts part of the spending on social assistance to spending on the working tax credit. It should be noted here that our simulations assume a $100 \%$ benefit take up rate of the tax credit and of social assistance. Indeed, several households in Germany have a positive labor supply, despite being in the social assistance benefit range (with its 100\% EMTR). Such behavior is consistent with the supposed high social stigma of claiming benefits. ${ }^{13}$

As expected from the discussion on framework conditions, the number of actual recipients is of comparable size. Eligibility is slightly higher in Finland (10.6\% of the households) and in France

\footnotetext{
${ }^{13}$ Other dynamic considerations may explain such behavior as well, namely the fact that working brings entitlement to pension rights or career expectations dependent on past employment records.
} 
(10.1\%) than in Germany (9\%). The difference between France and Finland is indeed quite small, which is consistent with differences in potential eligibility and income distribution.

The distribution of the budgetary cost across the different household typologies is indeed driven by the differences in the structure of the population: Germany and France share a similar structure of spending, with over $50 \%$ accruing to couples with children and over $40 \%$ shared more or less equally between singles and lone parents. Compared to Germany, France is characterized by a significantly lower share of singles, but also by a higher share of eligible households, while the high employment rate of females in couples implies lower expenditure on this household type. The same arguments apply to explain the different structure of spending in Finland: the share of singles is slightly higher than in Germany, but the employment rate is also rather high. On the other hand the share of females (and especially non mothers) in employment is higher than in France which implies that even fewer couples are entitled to the benefit.

\subsection{Effects on poverty}

The distributive impact of the reform has been analyzed by comparing poverty indicators before and after the reform. ${ }^{14}$

Tab. 4 shows that the reform achieves significant poverty reduction in France as the poverty rate declines from $7.03 \%$ to $6.38 \%$. In Germany, the reduction is not as large: poverty rate is reduced from $11.18 \%$ to $10.69 \%$. Such result is consistent with less net per capita spending. In Finland, the reduction is almost null when looking at the $50 \%$ poverty line, which suggests that the working poor phenomenon is less developed in the Nordic country. There is however a significant poverty reduction if the $60 \%$ poverty line is considered, which means that the reforms redistribute relatively more to the 'richest' among the poor households in all countries.

The latter shows that the tax credit is indeed not the most appropriate instrument, if the aim of the policy is to redistribute income, as the WTC only targets the 'working poor' which are significantly less poor than inactive households.

The efficiency cost of the reform, however, i.e. the cost per year per household taken out of poverty, is extremely high. With a more conservative definition of poverty (i.e. fixing poverty line at 50\%) the efficiency cost ranges from over EUR 38.000 in France to about EUR 113.000 in Germany and over EUR 840.000 in Finland. With a more liberal definition of poverty line (i.e. $60 \%$ of median equivalent income), the net cost per household out of poverty are substantially lower: EUR 14.600, EUR 33.800 and EUR 54.600 for France Germany and Finland respectively. Arguably, efficient activation measure could reach a significantly higher poverty reduction target at a much lower efficiency cost.

\footnotetext{
${ }^{14}$ Mantovani and Sutherland (2001) compare poverty rates obtained using EUROMOD and national official figures. Figures are quite in line for France (the 1997 Fiscal Data give 6.9\% with a poverty line at 50\%) and Finland (the 1999 Income Distribution Survey gives 4\%). Differences are somewhat larger in Germany (the 1999 GSOEP gives $8.2 \%$ ), which is due to assuming $100 \%$ take-up of welfare assistance (Sozialhilfe). Notwithstanding, we are primarily concerned here with relative moves in and out of poverty under both reforms than with the absolute level of headcount ratios.
} 
Yet these are only first round effect. In the next paragraph we will briefly discuss potential labor supply reactions, and argue that efficiency cost might be even higher.

\section{$5 \quad$ Potential Labor Supply Reactions}

\subsection{Effective Marginal Tax Rates}

A common way to characterize potential work disincentives at the intensive margin consists in computing the distribution of EMTRs in the population. EMTRs indeed measure the size of the distortions generated by the tax-benefit system, that is, the fraction which is levied from marginal additional income. This includes increased taxes to be paid but also the partial loss of means tested benefits. Changes in EMTRs then correspond to changes in implicit wages. ${ }^{15}$

Figure 3 shows the distribution of mean EMTR by decile of equivalent disposable income for the whole population, EMTRs being averaged over active and potentially active households of each decile only (i.e. household head must be between 25 and 60 year old, neither disabled, nor in full time education or retired). ${ }^{16}$

The U-shaped distribution we find in France and Finland is typical in several EU countries. In the upper part of the distribution, these rates are explained by the progressiveness of the income tax schedule, while they are due to the means-testing of social assistance at the bottom. In France, the overall level of taxation is lower so that EMTRs are lower than in Finland, except in the first decile (which is hardly concerned by income taxes). The Finnish curve is fairly smooth while the anomalies in the French curve are mainly due to thresholds in means-tested transfers to families and to income tax rebates.

In Germany, the aforementioned disregard of labor income for social assistance assessment is very small but sufficient to explains lower EMTR for the first decile which contains most of the inactive households, ${ }^{17}$ while ceiling on SSC explain the decreasing profile of EMTRs in the top

\footnotetext{
${ }^{15}$ In principle, EMTRs could be computed analytically as one minus the first derivative of the budget constraint. However, the complexity of the tax-benefit system forces us to rely on a numerical approximation. We therefore rely on EUROMOD to simulate the increase in disposable income $(d C)$ following an increase in gross employment income $(d y)$ of household heads (defined as the main earner in the household). The formula is simply:

$$
E M T R=1-\frac{d C}{d y}
$$

We choose a uniform gross income increment $d y=1500$ EUR per year for all three countries. Note also that the increment is larger than what one may think of as 'marginal'. Yet, this choice corresponds to an additional productive effort that can be seen as more realistic than an additional euro of income. Indeed, it corresponds to around 5 additional hours per week for a worker paid at the minimum wage. In particular, the choice to link the 'marginal' increase in income to an increase in working hours allows to capture the negative effect of the tax benefit system on an increase in working effort, rather than an increase in productivity (the wage rate is infact not a variable under direct control of a worker - at least not in the short run).

${ }^{16}$ It is important to note that the distribution of EMTRs is quite heterogenous within each decile, due to the complexity of tax-benefit systems and the fact that deciles are computed on income per unit of consumption. To illustrate this point, notice for instance that the EMTR of the first decile does not reach 100\%, which would be the case if it was composed only by inactive households.

17 This point depends crucially on the EMTR definition. In our computations, the 1500 EUR yearly increment implies that inactive households of the first decile are assumed to switch from 0 to 125 EUR per month of earnings,
} 
of the distribution. ${ }^{18}$ In Germany and Finland, high EMTRs in lower deciles 2 to 4 are due to the means-testing of generous transfers observed on budget curves above. This not the case in France where housing benefits present lower withdrawal rates and assure a relatively larger part of the transfers compared to the other countries. This feature, together with a lower level of income taxation, mainly explains the difference with Finland and Germany. It is important to recall that the EMTRs computed in this paper account for social security contributions (SSC) in addition to direct taxes and transfers. ${ }^{19}$ This explains the lower general level of EMTR curves compared to Bourguignon (1997) and turns out to be important in the German case. ${ }^{20}$

A priori, with the tax credit, average tax rates are decreased at the expense of an increase in EMTRs over the whole range of the benefit. EMTRs should decrease only for those households close to the eligibility threshold, and increase for all households in the phase-out range as the amount of the transfer decreases with increments in gross income. ${ }^{21}$ Numerical simulations confirm this intuition: EMTRs increase substantially for deciles 3, 4 and 5, given the large phasing-out of the transfer. Despite the fact that the amount of the benefit is the same in the three countries, the rise is effectively more important in France where taxation is relatively lower. Finland starts out from a situation of high marginal income tax rates so that a smaller part of the gross increase will be taxed away in the phase-out region. The same applies to Germany, although the increase in EMTRs starts only at the third decile (the second in Finland). This is probably related to the greater importance of (flat rate) social security contributions rather than of progressive income taxation in Germany, so that low earnings are relatively more taxed than in Finland (hence EMTR rise relatively less at the bottom).

Two reasons explain why EMTRs decrease in the first two deciles in Germany. Firstly, the 16 hours threshold for eligibility may induce negative EMTRs in the cases where the increment makes the household eligible for the tax credit; this is more often the case in Germany due to a larger proportion of households below the 16 hours threshold. Secondly, the tax credit crowds out social assistance for low income household in activity; this way, the implicitly taxation of additional gross earnings switches from $100 \%$ (withdrawal rates of minimum income schemes) to $\frac{d z}{d y} t$. In all

only 55 EUR of which will be considered in the income assessment due to the 70 EUR disregard. In that case, the benefit withdrawal rate is $30 \%$, so that EMTR will be only $13.2 \%$. Additional disregards for workers with children may bring the withdrawal rate down. This effects naturally explain the relatively lower mean EMTR in the first decile in Germany. A 'truly marginal' increment would imply full disregard hence 0 EMTRs for inactive households.

18 The funding of the German social security system is characterized by contribution assessment limits, i.e. maximum amounts from which the contributions to the state insurances fund are calculated, even if an employee earns more. In 1998, the contribution assessment limit was around 4000 EUR per month (the assessment limit varies in accordance to whether the region is in East or West Germany and to the risk ensured).

19 The choice to treat these contributions as taxes is highly debatable but can be justified to some extent. We do not go into details here and refer to Bourguignon (1997) for a more in-depth discussion.

${ }^{20}$ In addition, some instruments have changed since the reference year in Bourguignon (1997), which explain that the mean EMTR has decreased for the first decile. In particular, the additional disregard for social assistance has been brought up from $15 \%$ to $30 \%$ of income higher than 70 EUR.

${ }^{21}$ Firstly, the EMTR increases by the level of the taper rate $t=55 \%$, corrected by the fact that this withdrawal rate applies to the income concept $z$ (labor income net of tax and social security contributions plus some benefits) rather than to gross earnings $y$. 
countries, the reform mostly targets the first half of the distribution so that EMTRs of deciles 6 to 10 hardly change.

Table 5 shows the distribution of households, according to the range of EMTRs they face. The share of households facing high EMTRs (over 60\%) is considerable in the case of Germany and Finland, although the highest concentration of households is found in the bracket $40-50 \%$. In France, on the other hand, the greatest majority of the household face EMTRs in the $30-40 \%$ bracket. Introducing the reform, however, considerably changes the distribution: the share of household facing high marginal tax rates increases by a few percentage points in Finland and in Germany ( +7.2 and +8.1 respectively) and by over 12 in France. Interestingly, the most significant increase is in the share of household facing extremely high EMTRs. The difference is due to the fact that in the WTC phase out range, the withdrawal of the working tax credit cumulates with the withdrawal of the housing benefit in France, but not in the other countries.

These results are not comparable with the effects found in the UK, since one of the objectives of the WFTC was to partly reduce the disincentive effect embedded in the high taper rate of the Family Credit. Following the decrease in the taper rate the number of households with an EMTR above $70 \%$ decrease by around 450, 000 while households with an EMTR above $50 \%$ increase by about the same amount, since the lower taper rate extended the phasing out of the benefit to higher ranges in the income distribution.

\subsection{Financial Gains To Work}

Financial gains to work when moving from inactivity to full time or part time employment provide further insights on the interaction of the reform with each country's tax and benefit system. Differently from the analysis of the EMTRs, the analysis of the financial gains to work helps understanding the reshaping of financial incentives to work at the extensive margin. To compute financial gains to work we simulate the disposable income when women in working age work 0,20 or 40 hours. The financial gain to take up work is then just the ratio of disposable income when working part-time or full-time to income out of work.

Gross income when working part-time or full-time have been imputed assuming constancy of the current wage rate for women in employment. In the case of inactive women, the wage rate was imputed using the usual Heckman technique. Table 6 shows the regression coefficients of female hourly wage (in logs) using a two step Heckman selection model. The coefficients all have the expected signs, both in the wage equation and in the selection equation. ${ }^{22}$

Tables 7 and 8 show the result for single and married women respectively, under the pre reform and post reform scenario.

For women in couples, the gains of working full time are on a similar average level for Germany and France and slightly higher for Finland (principally due to the individualized tax system),

\footnotetext{
${ }^{22}$ As stressed by Ermisch and Wright (1994), negative selection bias is consistent with both positive and negative inverse mill ratio terms. In all countries average predicted wage using Heckman selection correction was significantly higher, then when using the coefficients of a standard regression model.
} 
but the share of low gains is higher in France and in Germany, than in Finland. On the other hand, the share of single women with low financial gains to work is incredibly high in Germany (owing to generous assistance towards single mothers), and to a less extent in Finland, whereas the concentration is much lower in France.

The tax credit transfers lead to a significant increase in financial gains to work for single women. This is particularly striking as regards the gain of working part-time, which rises from 47 to $79 \%$ (resp. 67 to $91 \%$ and 56 to $81 \%$ ) in France (resp. Germany and Finland) after implementation of the reform. The average gain of working full-time increases by 7 percentage points in Finland and by more than 10 points in Germany and France. Similarly, the proportion of very low gains (less than 40\%) decreases substantially when the tax credit is introduced, and this for all three countries.

For married women the picture is completely different. First, it is noticeable and expected that the gain is much smaller than for single individuals; this is especially the case in France and Germany where the earnings of the second-earner are taxed away at the marginal tax rate of the first earner, as a consequence of the joint income taxation system. The same holds for the tax credit for which income is jointly assessed at the household level. As a result, additional earnings by wives may lead to a loss in the tax credit entitlement for their working partners. The gain of working full time thus shifts from 58 to $54 \%$ (resp. 58 to $53 \%$ and 65 to $61 \%$ ) in France (resp. Germany and Finland). Besides average figures, the distribution in table 8 reveals that the proportion of small gains associated to working full-time (less than 30\%) will increase drastically in France (from $9.5 \%$ to $20 \%$ of the selected women) and more moderately in Germany and Finland (from 17 to $23 \%$ and from 7.7 to $10.8 \%$ respectively).

\subsection{Labor Supply Elasticities}

The increase in the EMTRs might indeed have a negative impact on labor supply at the intensive margin, however, many workers are indeed constrained by demand side rigidities and may not adjust their labor supply in a fully flexible way.

The incentives to take up work increase significantly for singles and single mothers, but are equally substantially reduced for women in couples. How household members would adjust to such a modification in the budget constraint is however difficult to anticipate.

A reliable analysis of potential behavioral reactions relies on the estimation of unobserved structural parameters which relate to preferences and in fixed costs of labor supply. These aspects are usually summarized in indicators of labor supply responsiveness (i.e. labor supply elasticities). A fully structural labor supply model would allow to identify preference parameters and fixed cost of labor supply, which would then be used to anticipate optimal behavior in the post reform scenario. Bargain and Orsini (2004) follow Blundell, Duncan, McCrae, and Meghir (2000) and evaluate the second round effect of different in work policies using a structural model of labor supply. Such procedure, however, relies heavily on the specified functional form and on the assumed distribution of disturbances. The ex-ante analysis by Blundell, Duncan, McCrae, and Meghir (2000), for 
example, correctly evaluated the direction of potential responses to the WFTC, but significantly underestimated the effect of the reform, when compared with the ex-post analysis of Brewer and Shephard (2004), who rely on a 'difference in difference' estimation methodology.

Table 9 summarizes some recent estimates of female labor supply elasticities. The main conclusion is that overall labor supply elasticities are indeed quite small in continental Europe and in Finland; the range of variation of the estimate, however, is rather high. Some broad conclusions may nevertheless be drawn: consistently with economic theory, wage elasticities of single women are significantly lower than elasticities of married or cohabiting women. The significant exception of Finland, reported by Bargain and Orsini (2004) should deserve further analysis.

In Finland, moreover, elasticities seem to be significantly lower than in Germany and in France, whereas the differences in the size of labor supply of France and Germany are not consistent across studies.

It is interesting to remark that behavioral reactions are likely to be stronger amongst the population negatively affected by the reform, and weakest amongst singles and single mothers.

\section{Concluding Remarks}

In this study, we have compared 'framework conditions' relevant for introducing a pseudo WFTC in three EU countries - Finland, France and Germany - afflicted by potential inactivity traps. Such 'framework conditions' not only help understanding the differences in the first round effects of introducing a refundable tax credit, but may also be helpful in speculating over potential second round effects. The analysis suggests that while first round redistributive effect might indeed be significant, the impact on overall employment rate could be reasonably expected to be very small, or even negative due to different composition effect. ${ }^{23}$ In this case the relatively high efficiency cost of lifting a household over the poverty line might become even larger, whereas the objective of increasing employment rates would clearly be out of reach. On the other hand, if the objective is not an increase in the employment rate per se, but an improvement for most disadvantaged groups, like indeed lone mothers, the tax credit could be a desirable policy for Germany, but indeed not for Finland and even less so for France, which shows already high employment rates for single mothers. Increasing the employment rate of singles and lone mothers - even at the expense of a decrease in the employment rate of women in couple, might in turn bring to positive externalities as described by Phelps (2000). ${ }^{24}$ Should the rising trend in lone motherhood continue in the near future and approach the British figures, moreover, the evaluation on the need of such

\footnotetext{
${ }^{23}$ Naturally, the poverty criterion is only one among several distributional aspects, and the evaluation of the policy changes significantly according to the definition of the poverty line. In this respect it is evident that the working tax credit achieves an important transfer to the first-half of the income distribution but concentrates on the "working poor', thus neglecting the households in the very bottom of the income distribution.

${ }^{24}$ Phelps argues that there are potentially important social and economic externalities associated with entering the labor market (he insists on the fact to hold a full-time job): "Bringing marginalized groups, including those who work in the underground economy, into mainstream economic activities may generate beneficial outcomes for society as a whole, for example through the amelioration of problems like crime, social destitution, drug etc."
} 
policy could change dramatically - especially in Germany where inactivity traps for lone mothers are significantly higher. An alternative approach, could then be to design a policy measure which only benefit lone mothers as is in the case in the Canadian experimental Self Sufficiency Program $(\mathrm{SSP}) .^{25}$

Another alternative to avoid the potential negative impacts on women in couples would be to completely individualize the credit. The debate on the unit of assessment for such in work benefit is extremely up to date, and a second generation of making work pay policies seem to depart more and more from the original Anglo-Saxon scheme. This is partially the case in France, where inwork benefits are simultaneously conditioned on households means being under a rather generous income threshold and individual wage rate being smaller than 1.4 times the minimum wage. ${ }^{26}$ In the Netherlands a recent tax reform has introduced a tax credit on earned income that not only is purely individualized, but is also not tapered away as income increases. The potential high cost of such reform, however, has pushed policymakers to prefer a non-refundable tax credit, which reduces considerably the scope for positive labor supply reactions. ${ }^{27}$ In the Belgian tax reform, finally, the tax credit is also totally individualized, but differently from the Dutch case it is phased in and phased out. The small amount of the credit is however not likely to induce to a massive participation effect, but it is the idea of the government to substantially increase the level of the tax credit in the future. ${ }^{28}$

Bargain and Orsini (2004) use a structural labor supply model to assess the second round effects the tax credit described in this paper and of an individualized measure having the same budgetary cost in the same three countries. They conclude that, although only the individualized measure may be realistically expected to achieve an increase in employment, the efficiency cost with respect to both the employment and poverty reduction objectives remain extremely high. In fact, while the lack of targeting of an individualized credit avoids the disincentive effect on second earners, the dispersion of the benefit over low skilled workers living in middle-class and well off households implies significantly lower amounts.

It therefore seems that, despite the great attention triggered by the reform of the Family Credit in the UK, the current interest in 'making work pay' policies is destined - in the medium run to fade away. At least in Continental Europe and in Scandinavia the attention should be shifted towards demand side policies (given the level of structural involuntary unemployment) and active labor market policies that aim at permanently increasing the productivity of less skilled workers. A short-sighted alternative strategy, triggered by the current budgetary difficulties in France and

\footnotetext{
${ }^{25}$ See Foley, Ford, Gyarmati, Michalopoulos, Miller, Morris, Redcross, Robins, and Tattrie (2002) for a description of the program and an evaluation of its effects.

${ }^{26}$ See Bargain and Terraz (2003) for a description of the reform and an evaluation of its potential labor supply effects.

${ }^{27}$ For a detailed description of the reform and an analysis on the potential labor supply effects, see Van Soest and Das (2000).

${ }^{28}$ Orsini (2005) analyzes the Belgian tax reform and models its impact on female labor supply. The author finds that the effects are moderate, but they are mostly coming from other aspects of the reform, and not from the credit itself.
} 
in Germany, is to substantially reduce entitlement to social assistance, by requiring some form of participation in the labor market. The debate over the Revenue Minimum d'Activité in France or the Harz IV reform in Germany point indeed in this direction. Rather than 'making work pay', however, these reforms will most probably further inflate the number of 'working poor'. 
Fig. 1: Yearly amount of the tax credit by total hours

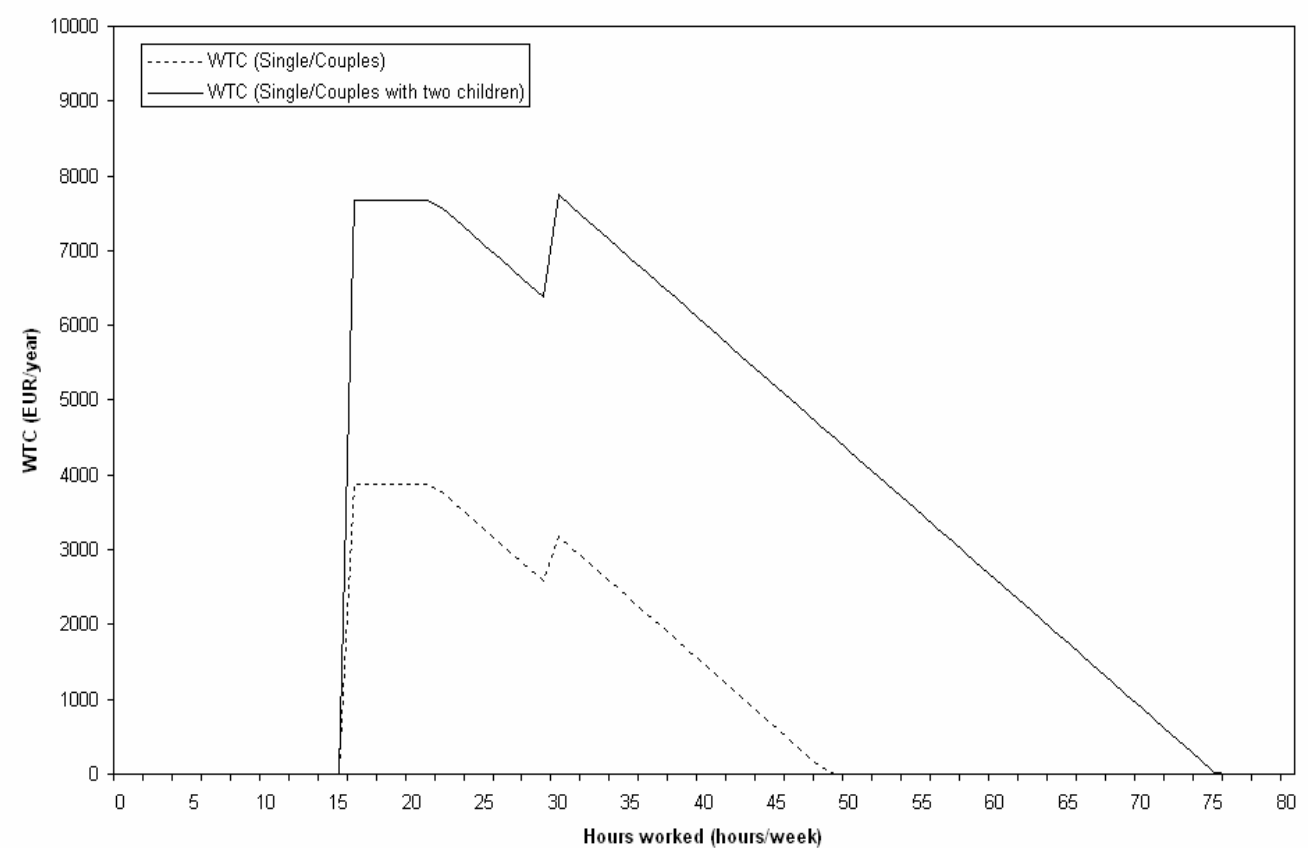

Net hourly wage of 6 EUR/week. 

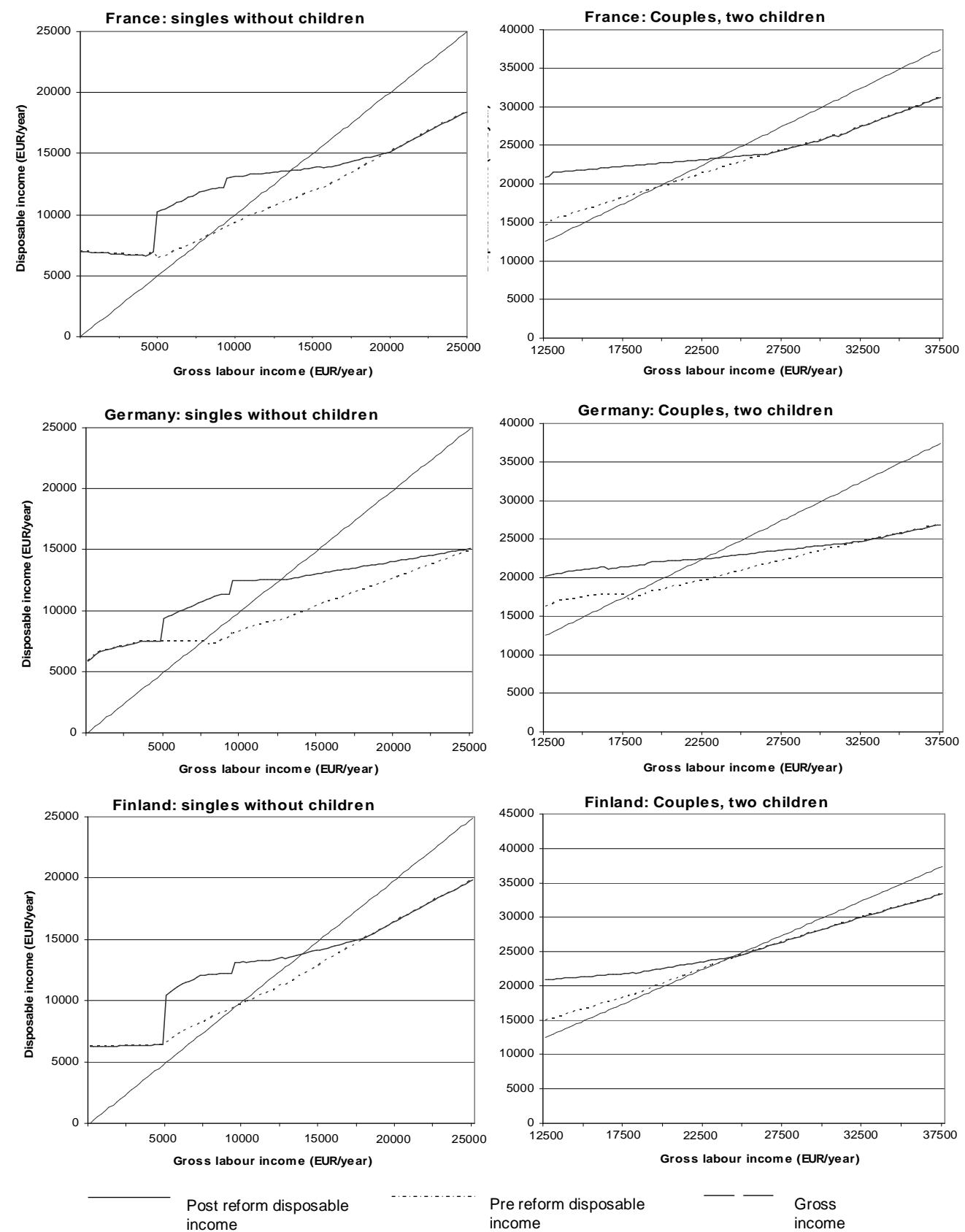

Net hourly wage of 6 EUR/week. 
Tab. 1: Distribution of households according to income ranges in WTC rules

\begin{tabular}{|c|c|c|c|}
\hline & France & Germany & Finland \\
\hline Not eligible & $29.8 \%$ & $43.2 \%$ & $33.5 \%$ \\
\hline Potentially eligible $^{1}$ & $70.2 \%$ & $56.8 \%$ & $66.5 \%$ \\
\hline Maximum benefit & $1.1 \%$ & $0.3 \%$ & $0.4 \%$ \\
\hline In benefit phase out range & $13.1 \%$ & $11.7 \%$ & $14.3 \%$ \\
\hline Out of benefit range & $56.0 \%$ & $44.8 \%$ & $51.8 \%$ \\
\hline
\end{tabular}

Tab. 2: Distribution of households types according to female employment status

\begin{tabular}{|c|c|c|c|c|c|c|}
\hline & \multicolumn{2}{|c|}{ France } & \multicolumn{2}{|c|}{ Germany } & \multicolumn{2}{|c|}{ Finland } \\
\hline & not emplo & mployed & not emplo & mployed & not emplo & employed \\
\hline Single males & \multicolumn{2}{|c|}{$6.6 \%$} & \multicolumn{2}{|c|}{$10.3 \%$} & \multicolumn{2}{|c|}{$11.4 \%$} \\
\hline Single females & $2.1 \%$ & $5.0 \%$ & $2.9 \%$ & $7.0 \%$ & $3.2 \%$ & $6.7 \%$ \\
\hline Single mothers & $0.3 \%$ & $2.6 \%$ & $1.4 \%$ & $2.2 \%$ & $0.7 \%$ & $2.7 \%$ \\
\hline \multicolumn{7}{|l|}{ Total single adult } \\
\hline Couples, no children & $4.6 \%$ & $8.0 \%$ & $3.9 \%$ & $9.1 \%$ & $3.6 \%$ & $11.9 \%$ \\
\hline Couples with children & $6.3 \%$ & $17.7 \%$ & $5.4 \%$ & $7.9 \%$ & $3.8 \%$ & $15.0 \%$ \\
\hline Total couples & \multicolumn{2}{|c|}{$36.5 \%$} & \multicolumn{2}{|c|}{$26.3 \%$} & \multicolumn{2}{|c|}{$34.3 \%$} \\
\hline
\end{tabular}

${ }^{1}$ Households with one adult employee working at least 16 hours Source: Authors' computations using EUROMOD. 
Tab. 3: Aggregate impact of introducing the tax credit

\begin{tabular}{|c|c|c|c|c|c|c|}
\hline & & all & singles & $\begin{array}{l}\text { lone } \\
\text { parents }\end{array}$ & couples & $\begin{array}{c}\text { couples } \\
\text { with children }\end{array}$ \\
\hline \multicolumn{7}{|l|}{ France } \\
\hline apparent cost & $\begin{array}{c}\text { (billion euros/year) } \\
\text { (\% of } 1998 \text { GDP) }\end{array}$ & $\begin{array}{c}5.859 \\
0.404 \%\end{array}$ & $22.5 \%$ & $20.3 \%$ & $2.3 \%$ & $54.9 \%$ \\
\hline net cost & $\begin{array}{c}\text { (billion euros/year) } \\
\text { (\% of } 1998 \text { GDP) }\end{array}$ & $\begin{array}{c}5.741 \\
0.395 \%\end{array}$ & $22.5 \%$ & $19.9 \%$ & $2.3 \%$ & $55.4 \%$ \\
\hline recipients & $\begin{array}{c}(\text { no of hh }) \\
\text { (\% of population) }\end{array}$ & $\begin{array}{c}2,316,233 \\
10.1 \%\end{array}$ & $34.3 \%$ & $16.3 \%$ & $4.5 \%$ & $44.9 \%$ \\
\hline $\begin{array}{l}\text { net average amount } \\
\text { net max amount }\end{array}$ & $\begin{array}{l}\text { (euros/week) } \\
\text { (euros/week) }\end{array}$ & $\begin{array}{c}49 \\
205\end{array}$ & $\begin{array}{l}32 \\
90\end{array}$ & $\begin{array}{c}60 \\
194\end{array}$ & $\begin{array}{l}25 \\
62\end{array}$ & $\begin{array}{c}59 \\
205\end{array}$ \\
\hline \multicolumn{7}{|l|}{ Germany } \\
\hline apparent cost & $\begin{array}{c}\text { (billion euros/year) } \\
\text { (\% of } 1998 \text { GDP) }\end{array}$ & $\begin{array}{c}7.662 \\
0.356 \%\end{array}$ & $20.9 \%$ & $23.7 \%$ & $2.2 \%$ & $53.2 \%$ \\
\hline net cost & $\begin{array}{c}\text { (billion euros/year) } \\
\text { (\% of } 1998 \text { GDP) }\end{array}$ & $\begin{array}{c}6.221 \\
0.289 \%\end{array}$ & $23.9 \%$ & $21.4 \%$ & $2.0 \%$ & $52.8 \%$ \\
\hline recipients & $\begin{array}{c}(\text { no of hh }) \\
(\% \text { of population })\end{array}$ & $\begin{array}{c}3,443,208 \\
9.0 \%\end{array}$ & $31.6 \%$ & $15.7 \%$ & $4.2 \%$ & $48.5 \%$ \\
\hline $\begin{array}{l}\text { net average amount } \\
\text { net max amount }\end{array}$ & $\begin{array}{l}\text { (euros/week) } \\
\text { (euros/week) }\end{array}$ & $\begin{array}{c}43 \\
149\end{array}$ & $\begin{array}{l}28 \\
90\end{array}$ & $\begin{array}{c}65 \\
120\end{array}$ & $\begin{array}{l}23 \\
57\end{array}$ & $\begin{array}{c}47 \\
149\end{array}$ \\
\hline \multicolumn{7}{|l|}{ Finland } \\
\hline apparent cost & $\begin{array}{c}\text { (billion euros/year) } \\
\text { (\% of } 1998 \text { GDP) }\end{array}$ & $\begin{array}{c}0.506 \\
0.394 \%\end{array}$ & $41.9 \%$ & $18.0 \%$ & $1.3 \%$ & $38.9 \%$ \\
\hline net cost & $\begin{array}{c}\text { (billion euros/year) } \\
\text { (\% of } 1998 \text { GDP) }\end{array}$ & $\begin{array}{c}0.492 \\
0.383 \%\end{array}$ & $42.1 \%$ & $18.4 \%$ & $1.1 \%$ & $38.4 \%$ \\
\hline recipients & $\begin{array}{c}(\text { no of hh }) \\
(\% \text { of population })\end{array}$ & $\begin{array}{c}248,663 \\
10.6 \%\end{array}$ & $53.7 \%$ & $14.4 \%$ & $1.7 \%$ & $30.2 \%$ \\
\hline net average amount & (euros/week) & 39 & 31 & 49 & 30 & 50 \\
\hline net max amount & (euros/week) & 248 & 90 & 159 & 53 & 248 \\
\hline
\end{tabular}

Source: Authors' computations using EUROMOD.

Tab. 4: Distributive impact of introducing the tax credit

\begin{tabular}{crrrrrr}
\hline \hline & \multicolumn{2}{c}{ France } & \multicolumn{2}{c}{ Germany } & \multicolumn{2}{c}{ Finland } \\
& Pre reform & Post reform & Pre reform & Post reform & Pre reform Post reform \\
\hline median equivalent & & & & & & \\
income (EUR/month) & 1,222 & 1,225 & 1,246 & 1,249 & 1,090 & 1,124 \\
poverty rate - $60 \%$ of median & $14.00 \%$ & $12.29 \%$ & $11.18 \%$ & $10.69 \%$ & $11.97 \%$ & $11.59 \%$ \\
number of hhs out of poverty 1 & & $-393,110$ & & $-183,836$ & $-8,966$ \\
poverty rate - 50\% of median & $7.03 \%$ & $6.38 \%$ & $5.65 \%$ & $5.51 \%$ & $3.75 \%$ & $3.72 \%$ \\
number of hhs out of poverty & & $-150,121$ & & $-54,654$ & -583 \\
\hline \hline
\end{tabular}

${ }^{1}$ Poverty rates in post-reform scenarios are computed on the basis of the pre-reform poverty line. Source: Authors' computations using EUROMOD. 


\section{France}
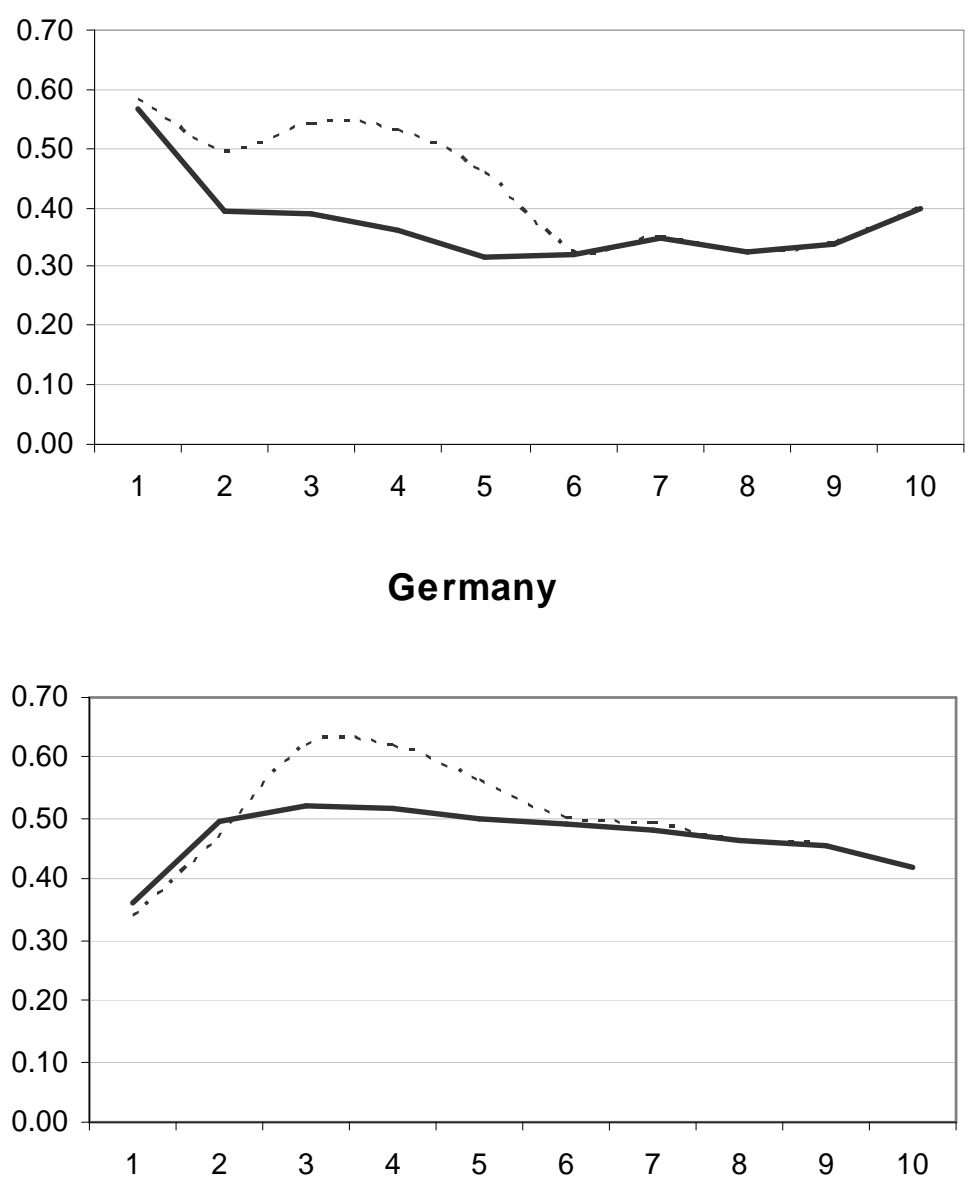

Finland

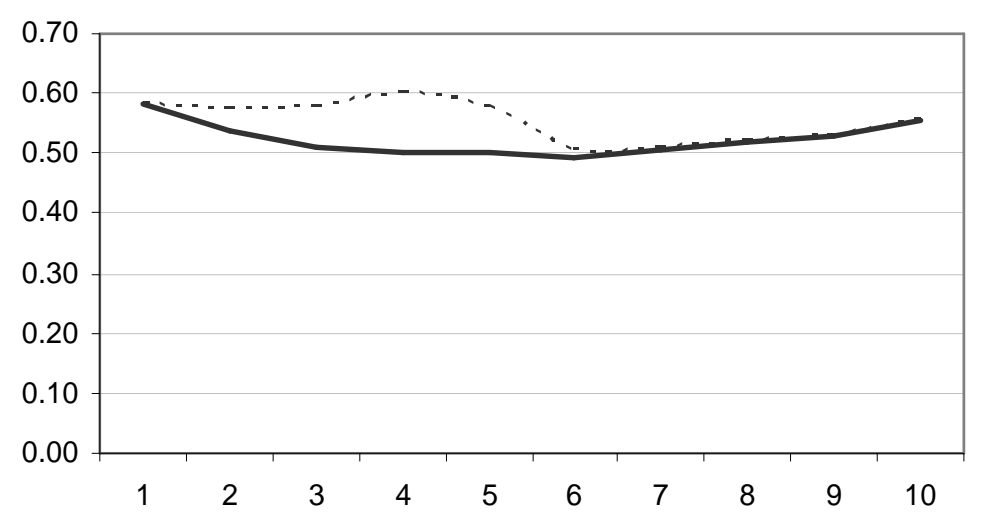

Pre reform -.... Post reform 
Tab. 5: Distribution of households by EMTR bracket

\begin{tabular}{rrrrrrr}
\hline \hline \multicolumn{2}{c}{ EMTR } & \multicolumn{2}{c}{ France } & \multicolumn{2}{c}{ Germany } & \multicolumn{2}{c}{ Finland } \\
& Pre reform & Post reform & Pre reform & Post reform & Pre reform Post reform \\
\hline in $[0.0 ; 0.1]$ & $0.1 \%$ & $0.2 \%$ & $0.6 \%$ & $0.8 \%$ & $0.0 \%$ & $0.0 \%$ \\
in $[0.1 ; 0.2]$ & $0.5 \%$ & $0.5 \%$ & $4.3 \%$ & $4.3 \%$ & $0.5 \%$ & $0.5 \%$ \\
in $[0.2 ; 0.3]$ & $21.3 \%$ & $3.1 \%$ & $5.5 \%$ & $5.4 \%$ & $0.2 \%$ & $0.2 \%$ \\
in $[0.3 ; 0.4]$ & $53.0 \%$ & $40.5 \%$ & $2.5 \%$ & $2.2 \%$ & $2.6 \%$ & $2.6 \%$ \\
in $[0.4 ; 0.5]$ & $12.9 \%$ & $10.5 \%$ & $10.9 \%$ & $10.7 \%$ & $4.9 \%$ & $4.6 \%$ \\
in $[0.5 ; 0.6]$ & $3.6 \%$ & $3.1 \%$ & $17.2 \%$ & $15.6 \%$ & $32.9 \%$ & $28.5 \%$ \\
in $[0.6 ; 0.7]$ & $1.0 \%$ & $3.1 \%$ & $50.0 \%$ & $44.0 \%$ & $45.6 \%$ & $43.1 \%$ \\
in $[0.7 ; 0.8]$ & $0.5 \%$ & $3.6 \%$ & $3.1 \%$ & $3.2 \%$ & $7.6 \%$ & $7.1 \%$ \\
$>0.8$ & $3.8 \%$ & $11.3 \%$ & $1.6 \%$ & $6.8 \%$ & $1.5 \%$ & $6.3 \%$ \\
\hline \hline
\end{tabular}

Source: Authors' computations using EUROMOD.

Tab. 6: Heckman two step wage regression

\begin{tabular}{|c|c|c|c|c|c|c|}
\hline & \multicolumn{2}{|c|}{ France } & \multicolumn{2}{|c|}{ Germany } & \multicolumn{2}{|c|}{ Finland } \\
\hline & Coeff. & St. Err. & Coeff. & St. Err. & Coeff. & St. Err. \\
\hline \multicolumn{7}{|l|}{ Hourly wage $(\ln )$} \\
\hline Secondary education & 0.2068 & 0.0173 & 0.0049 & 0.0323 & 0.0658 & 0.0659 \\
\hline Tertiary education & 0.4538 & 0.0248 & 0.1504 & 0.0389 & 0.2208 & 0.2261 \\
\hline More than tertiary education & 0.6627 & 0.0226 & 0.4772 & 0.0477 & 0.4940 & 0.5013 \\
\hline Age & 0.0616 & 0.0315 & 0.1927 & 0.0761 & 0.1965 & 0.1974 \\
\hline $\mathrm{Age}^{2}$ & -0.0007 & 0.0008 & -0.0045 & 0.0018 & -0.0043 & -0.0043 \\
\hline $\mathrm{Age}^{3}$ & $1.0 \mathrm{E}-06$ & $5.9 \mathrm{E}-06$ & $3.5 E-05$ & $1.4 \mathrm{E}-05$ & $3.2 \mathrm{E}-05$ & $3.1 \mathrm{E}-05$ \\
\hline Number of children & -0.0211 & 0.0080 & -0.0255 & 0.0201 & -0.0182 & -0.0198 \\
\hline Constant & 2.5458 & 0.4246 & 0.3828 & 1.0190 & 1.0617 & 1.0136 \\
\hline \multicolumn{7}{|l|}{ Employment status } \\
\hline Married & -0.4147 & 0.0637 & -0.0403 & 0.1835 & -0.0274 & 0.0612 \\
\hline Number of children & -0.2858 & 0.0212 & -0.7533 & 0.0840 & -0.9180 & 0.0669 \\
\hline Child $<2$ & -0.3262 & 0.0643 & -0.7553 & 0.0800 & -0.0465 & 0.0582 \\
\hline Child between 3 and 5 & -0.1868 & 0.0545 & -0.3062 & 0.0308 & -0.0609 & 0.0181 \\
\hline Age & 0.2050 & 0.0209 & 0.1429 & 0.0259 & 0.2795 & 0.0147 \\
\hline $\mathrm{Age}^{2}$ & -0.0029 & 0.0002 & -0.0020 & 0.0003 & -0.0034 & 0.0002 \\
\hline Secondary education & 0.4785 & 0.0495 & 0.5254 & 0.0576 & 0.0365 & 0.0438 \\
\hline Tertiary education & 1.2889 & 0.0787 & 0.6971 & 0.0750 & 0.5150 & 0.0510 \\
\hline More than tertiary education & 1.1882 & 0.0665 & 0.6537 & 0.1052 & 0.7075 & 0.0574 \\
\hline Other income $(\ln )$ & -0.1807 & 0.0228 & -0.1547 & 0.0137 & -0.2413 & 0.0121 \\
\hline Constant & -0.2457 & 0.4935 & -0.4769 & 0.5310 & -3.4901 & 0.3425 \\
\hline Lambda & 0.1166 & 0.0371 & -0.5543 & 0.0579 & -0.1073 & 0.0201 \\
\hline Number of obs. & \multicolumn{2}{|c|}{5210} & \multicolumn{2}{|c|}{3732} & \multicolumn{2}{|c|}{7925} \\
\hline Censored obs. & \multicolumn{2}{|c|}{1625} & \multicolumn{2}{|c|}{1013} & \multicolumn{2}{|c|}{4798} \\
\hline Uncensored obs. & \multicolumn{2}{|c|}{3585} & \multicolumn{2}{|c|}{2719} & \multicolumn{2}{|c|}{3127} \\
\hline Wald (Chi2, 11) & \multicolumn{2}{|c|}{2602.37} & \multicolumn{2}{|c|}{459.15} & \multicolumn{2}{|c|}{1396.75} \\
\hline Prob > Chi2 & \multicolumn{2}{|c|}{0} & \multicolumn{2}{|c|}{0} & \multicolumn{2}{|c|}{0} \\
\hline
\end{tabular}

Bold letters indicate significance at the $1 \%$-level, italic letters refer to the $5 \%$-level and underlined letters to the $10 \%$-level.

Source: Authors' computations using EUROMOD. 
Tab. 7: Impact of the reform on financial gains to work (singles)

\begin{tabular}{|c|c|c|c|c|c|c|}
\hline \multirow{2}{*}{$\begin{array}{c}\text { \% increase in disposable income } \\
\text { when working full time }\end{array}$} & \multicolumn{2}{|c|}{ France } & \multicolumn{2}{|c|}{ Germany } & \multicolumn{2}{|c|}{ Finland } \\
\hline & Pre-reform & Post-reform & Pre-reform & Post-reform & Pre-reform & Post-reform \\
\hline$<20 \%$ & $1.1 \%$ & $0.5 \%$ & $12.8 \%$ & $4.9 \%$ & $4.4 \%$ & $1.7 \%$ \\
\hline in $[20 \% ; 40 \%[$ & $6.5 \%$ & $1.7 \%$ & $10.4 \%$ & $8.6 \%$ & $8.9 \%$ & $4.6 \%$ \\
\hline in $[40 \% ; 60 \%[$ & $11.1 \%$ & $3.3 \%$ & $9.1 \%$ & $12.1 \%$ & $9.4 \%$ & $11.8 \%$ \\
\hline in $[60 \% ; 80 \%[$ & $15.8 \%$ & $9.2 \%$ & $11.0 \%$ & $11.5 \%$ & $9.4 \%$ & $8.4 \%$ \\
\hline in $[80 \% ; 100 \%[$ & $14.0 \%$ & $23.6 \%$ & $8.6 \%$ & $10.4 \%$ & $9.6 \%$ & $10.3 \%$ \\
\hline in $[100 \% ; 120 \%[$ & $10.5 \%$ & $19.6 \%$ & $6.6 \%$ & $9.5 \%$ & $7.9 \%$ & $10.6 \%$ \\
\hline in $[120 \% ; 140 \%[$ & $7.7 \%$ & $8.3 \%$ & $7.3 \%$ & $6.4 \%$ & $7.7 \%$ & $7.2 \%$ \\
\hline in $[140 \% ; 160 \%[$ & $6.6 \%$ & $6.6 \%$ & $7.3 \%$ & $7.5 \%$ & $8.4 \%$ & $8.9 \%$ \\
\hline$>160 \%$ & $26.7 \%$ & $27.3 \%$ & $26.9 \%$ & $29.1 \%$ & $34.3 \%$ & $36.5 \%$ \\
\hline average gain to work full time & $132.4 \%$ & $143.9 \%$ & $143.0 \%$ & $153.2 \%$ & $134.9 \%$ & $142.2 \%$ \\
\hline average gain to work part time & $47.0 \%$ & $78.7 \%$ & $67.2 \%$ & $90.6 \%$ & $56.2 \%$ & $81.0 \%$ \\
\hline
\end{tabular}

Gains are computed as percentage increase in disposable income when the female head is working part-time or full-time (20 and 40 hours week respectively) with respect to not working at all. Hourly wage is kept constant for population in employment or imputed using regression techniques (see text for details).

Source: Authors' computations using EUROMOD.

Tab. 8: Impact of the reform on financial gains to work (couples)

\begin{tabular}{|c|c|c|c|c|c|c|}
\hline \multirow{2}{*}{$\begin{array}{c}\% \text { increase in disposable income } \\
\text { when working full-time }\end{array}$} & \multicolumn{2}{|c|}{ France } & \multicolumn{2}{|c|}{ Germany } & \multicolumn{2}{|c|}{ Finland } \\
\hline & Pre-reform & Post-reform & Pre-reform & Post-reform & Pre-reform & Post-reform \\
\hline$<10 \%$ & $0.0 \%$ & $0.7 \%$ & $0.5 \%$ & $2.6 \%$ & $2.5 \%$ & $0.9 \%$ \\
\hline in $[10 \% ; 20 \%[$ & $2.2 \%$ & $5.9 \%$ & $5.4 \%$ & $7.9 \%$ & $1.7 \%$ & $3.6 \%$ \\
\hline in $[20 \% ; 30 \%[$ & $7.3 \%$ & $13.4 \%$ & $11.4 \%$ & $12.7 \%$ & $3.5 \%$ & $6.3 \%$ \\
\hline in $[30 \% ; 40 \%[$ & $15.1 \%$ & $17.9 \%$ & $14.6 \%$ & $14.6 \%$ & $7.8 \%$ & $10.0 \%$ \\
\hline in $[40 \% ; 50 \%[$ & $18.3 \%$ & $18.0 \%$ & $17.0 \%$ & $17.7 \%$ & $13.9 \%$ & $15.1 \%$ \\
\hline in $[50 \% ; 60 \%[$ & $17.8 \%$ & $14.8 \%$ & $14.6 \%$ & $12.9 \%$ & $15.4 \%$ & $16.6 \%$ \\
\hline in $[60 \% ; 70 \%[$ & $13.8 \%$ & $12.1 \%$ & $12.4 \%$ & $10.8 \%$ & $16.3 \%$ & $14.0 \%$ \\
\hline in $[70 \% ; 80 \%[$ & $9.1 \%$ & $6.4 \%$ & $7.6 \%$ & $7.0 \%$ & $13.6 \%$ & $12.4 \%$ \\
\hline$>80 \%$ & $16.4 \%$ & $10.8 \%$ & $16.5 \%$ & $13.9 \%$ & $25.4 \%$ & $21.1 \%$ \\
\hline average gain to work full time & $57.6 \%$ & $50.4 \%$ & $57.7 \%$ & $53.4 \%$ & $65.3 \%$ & $61.3 \%$ \\
\hline average gain to work part time & $29.7 \%$ & $24.5 \%$ & $31.1 \%$ & $28.6 \%$ & $37.0 \%$ & $34.6 \%$ \\
\hline
\end{tabular}

Gains are computed as percentage increase in disposable income when the female spouse is working part-time or full-time (20 and 40 hours week respectively) with respect to not working at all. Hourly wage is kept constant for population in employment or imputed using regression techniques (see text for details).

Source: Authors' computations using EUROMOD. 
Tab. 9: Labour Supply Elasticity: a Survey

\begin{tabular}{|c|c|c|c|c|}
\hline & Sample selection & Wage elasticity & Sample selection & Wage elasticity \\
\hline \multicolumn{5}{|l|}{ France } \\
\hline Bargain (2004) & $\begin{array}{l}\text { Married and cohabitating } \\
\text { females (either inactive } \\
\text { or employed) }\end{array}$ & 0.30 & - & \\
\hline Choné et al. (2003) & $\begin{array}{l}\text { Couples with one child } \\
\text { under the age of } 7\end{array}$ & 0.30 & - & \\
\hline Bargain and Orsini (2004) & $\begin{array}{l}\text { Married and cohabitating } \\
\text { females (either inactive or } \\
\text { in employment) } \\
\text { with partners in employment }\end{array}$ & 0.60 & $\begin{array}{l}\text { Inactive or employed } \\
\text { single women }\end{array}$ & 0.12 \\
\hline \multicolumn{5}{|l|}{ Germany } \\
\hline Bonin Kempe and Schneider (2002) & $\begin{array}{l}\text { Married and cohabitating } \\
\text { females in working age }\end{array}$ & 0.27 & - & \\
\hline Haan (2003) & $\begin{array}{l}\text { Married and cohabitating } \\
\text { females in working age }\end{array}$ & 0.32 & $\begin{array}{l}\text { Single females } \\
\text { in working age }\end{array}$ & 0.13 \\
\hline Haan and Steiner (2004) & $\begin{array}{l}\text { Married and cohabitating } \\
\text { females in working age }\end{array}$ & 0.39 & $\begin{array}{l}\text { Single females } \\
\text { in working age }\end{array}$ & 0.13 \\
\hline Bargain and Orsini (2004) & $\begin{array}{c}\text { Married and cohabitating } \\
\text { females (either inactive or } \\
\text { in employment) } \\
\text { with partners in employment }\end{array}$ & 0.40 & $\begin{array}{l}\text { Inactive or employed } \\
\text { single women }\end{array}$ & 0.16 \\
\hline \multicolumn{5}{|l|}{ Finland } \\
\hline Ilmakunnas (1992) & $\begin{array}{l}\text { Married and cohabitating } \\
\text { females in working age }\end{array}$ & 0.29 & - & \\
\hline Kusimanen (1997) & $\begin{array}{l}\text { Married and cohabitating } \\
\text { females in working age }\end{array}$ & 0.10 & - & \\
\hline Bargain and Orsini (2004) & $\begin{array}{l}\text { Married and cohabitating } \\
\text { females (either inactive or } \\
\text { in employment) } \\
\text { with partners in employment }\end{array}$ & 0.15 & $\begin{array}{l}\text { Inactive or employed } \\
\text { single women }\end{array}$ & 0.28 \\
\hline
\end{tabular}




\section{References}

Banks, J., R. Disney, A. Duncan, and J. van Reenen (2003): "The Internationalisation of Public Welfare Policy," The Economic journal, 115, 62-81.

BARgain, O. (2004): "Aides au retour à l'emploi et à l'activité des femmes en couple," Revue de l'OFCE, 88, 59-87.

Bargain, O., And K. Orsini (2004): "In-Work Policies in Europe: Killing Two Birds with One Stone," Labour Economics, forthcoming.

Bargain, O., And I. Terraz (2001): "EUROMOD country report for France," Euromod working paper.

(2003): "Evaluation et mise en perspective des effets incitatifs et redistributifs de la Prime pour l'Emploi," Economie et Prévision, 160/161, 124-149.

Bertola, G. (2000): "Policy Choices and Interactions with Existing Instruments," Economic studies, 31, 185-196, OECD.

Blundell, R., A. Duncan, J. McCrae, and C. Meghir (2000): "The Labour Market impact of the Working Families Tax Credit," Fiscal Studies, 21(1), 75-104.

Bourguignon, F. (1997): "Fiscalité et rédistribution," Report, Conseil d'Analyse Economique.

Bourguignon, F., and D. Bureau (1999): "L'architecture des prélèvements en France : état des lieux et voies de réforme," Report, Conseil d'Analyse Economique.

Brewer, M. (2003): "The New Tax Credits," Briefing note 35, IFS.

Brewer, M., A. Duncan, A. Shephard, and M. J. SuÁrez (2003): "Did Working Family Tax Credit work? Analysing the impact of in-work support on labour supply and programme participation," Working paper 2, Inland Revenue.

Brewer, M., And A. Shephard (2004): "Has Labour made work pay?," Discussion paper, Joseph Rowntree Foundation.

Bundesministerium für Wirtschafts und Technologie (2002): "Reform des Sozialstaats für mehr Bescheftigung im Berich gering qualifizierter Arbeit," Report, Bundesministerium für Wirtschafts und Technologie.

Eissa, N., And H. Hoynes (2004): "Taxes and the Labor Market Participation of Married Couples: The Earned Income Tax Credit," Journal of Public Economics, 88, 1931-1958.

ERmisch, J. F., And R. E. Wright (1994): "Interpretation of Negative Sample Selection Effect in Wage Offer Equations," Applied Economic Letters, 1, 187-189.

Ferry, J. P. (2000): "Plein Emploi," Report, Conseil d'Analyse Economique.

Foley, K., R. Ford, D. Gyarmati, C. Michalopoulos, C. Miller, P. Morris, C. RedCross, P. K. Robins, and D. Tattrie (2002): "Making Work Pay. Final Report on the Self-Sufficiency Project for Long-Term Welfare Recipients," Discussion paper, SRDC, Ottawa.

GrabKA, M. (2001): "EUROMOD country report for Germany," Euromod working paper.

HaAn, P., And V. Steiner (2005): "Distributional Effects of the German Tax Reform 2000: A Behavioral Microsimulation Analysis," Journal of Applied Social Science Studies, 125, 39-49.

Ilmakunnas, S., J. Kiander, P. Parkkinen, and A. Romppanen (2000): "Globalisation: the End of Work. The Economy and Employment in Finland to 2030," Report, Government Institute for Economic Research. 
Laine, V. (2002): "Changing poverty Post-1997," Working paper 63, Centre for Analysis of Social Exclusion.

Mantovani, D., And H. Sutherland (2001): "Social Indicators and other Income Statistics using the Euromod Baseline: a Comparison with Eurostat and National Statistics," Euromod working paper, em1/03.

MARtin, J., AND D.GRubB (2001): "What works and for whom: a review of OECD countries' experience of active labour market policies," Working paper, OECD.

Orsini, K. (2005): "The 2001 Belgian Tax Reform: Equity and Efficiency," Ces discussion paper no. 05-04.

Pearson, M. (2002): "International experience of 'making work pay' policies," Working paper, OECD.

Pearson, M., and S. Scarpetta (2000): "An Overview: What Do We Know About Policies to Make Work Pay?," Oecd economic studies, no. 31, 2000/ii.

Phelps, E. (2000): "The importance of inclusion and the power of job subsidies to increase it," OECD Economic Studies, 31, 85-114.

Pichaud, D., And H. Sutherland (2002): "Evaluating tax and benefit reforms in 1996-2001," Discussion paper 280, VATT.

Stephens, M., N. Burns, and L. Mackay (2002): Social market or safety net? British social rented housing in a European context. The Policy Press, Bristol.

Van Soest, A., And M. Das (2000): "Family labor supply and proposed tax reforms in the Netherlands," De Economist, 149, 191-218.

VitTAmÄKi, H. (2001): "EUROMOD country report for Finland," Euromod working paper. 